\title{
Investigation of wheat - Anchote (Coccinia abyssinica (Lam.)) composite flours and baking temperature for cookies production
}

\author{
${ }^{1}$ Melese, A.D., ${ }^{2}$ Abera, S. and ${ }^{3, *}$ Mitiku, D.H \\ ${ }^{1}$ Department of Chemical Engineering, Wollega University, Nekemte, Ethiopia \\ ${ }^{2}$ Department of Food Process Engineering, Haramaya University, Dire Dawa, Ethiopia \\ ${ }^{3}$ Department of Post harvest Management, Jimma University, Jimma, Ethiopia
}

Article history:

Received: 30 June 2020

Received in revised form: 3

August 2020

Accepted: 2 September 2020

Available Online: 29

November 2020

\section{Keywords:}

Anchote flour,

Cookies,

Functional properties,

Sensory analysis

DOI:

https://doi.org/10.26656/fr.2017.5(1).315

\begin{abstract}
A study was conducted on properties of Anchote (Coccinia abyssinica (Lam.)) flour and its application for cookie production by blending with wheat flour. The experiment was planned with two factors; Anchote blending ratios and baking temperatures. It consisted of nine combinations of treatments executed in a completely randomized design (CRD). The Anchote blending ratios were 10, 15 and $20 \%$ and the baking temperatures were 160,180 and $200^{\circ} \mathrm{C}$. The functional properties such as water absorption, oil absorption, swelling power, solubility and dispersibility of Anchote flour were $2.44 \mathrm{~g} / \mathrm{g}, 1.92 \mathrm{~mL} / \mathrm{g}, 11.48 \%$, $41.53 \%$ and $67.33 \%$ while those of the wheat flour was 1.84, 2.18, 9.08, 35.87 and 73.66 , respectively with the relevant units indicated. Increasing the blending ratio of Anchote significantly $(p<0.05)$ affected the functional properties of the composite flours. The physical properties of cookies of the composite flours such as spread ratio (6.87 to 10.07), specific volume $\left(1.6\right.$ to $\left.1.88 \mathrm{~cm}^{3} / \mathrm{g}\right)$ and hardness $(6.37$ to $17.54 \mathrm{~N})$ were significantly $(p<0.05)$ affected by the blending ratios and baking temperatures. Sensory acceptability data of cookies showed that increasing the blending ratio resulted in reduced scores of all attributes. However, all the scores were above 5.00 on the 7-point hedonic scale indicating positive acceptance. With regard to baking temperature the highest score for each attribute was scored for cookies baked at $180^{\circ} \mathrm{C}$. Thus, it can be concluded that Anchote flour can be blended with wheat flour up to $20 \%$ to produce cookies of good physical and sensorial acceptable quality.
\end{abstract}

\section{Introduction}

Root and tuber crops are plants grown all over the world in hot and humid regions, providing starchy roots, corms, rhizomes, stems and tubers. Anchote (Coccinia abyssinica (Lam.) Cogn.) is one of a tuber crop belongs to the Cucurbitaceae family and conccinia genus having over 30 species, about eight of which are believed to occur in Ethiopia (Mengesha et al., 2012; Bekele et al., 2013; Yambo and Feyissa, 2013; Yassin et al., 2013). Anchote is used to treat bone fractures and displaced joints among traditional communities in western Ethiopia. It has also potential importance to be used to fight protein deficiency in developing countries such as Ethiopia (Hora, 1995). Abebe and Hagos (1991) reported that juice prepared from Anchote has saponin as an active substance and is used to treat gonorrhea, tuberculosis and tumor cancer among local community in the western part of Ethiopia. Moreover, Anchote has been in use among local people to prepare a variety of food items for traditional ceremonies, special food for guests and animal fattening (Bekele, 2007).

Anchote tubers once harvested deteriorate rapidly, mainly due to physiological changes and mechanical damage during harvesting, transportation and handling. The very short storage life after harvest has been recognized as a limitation to the cultivation of the crop (Okaka and Okaka, 2001). As a result, growers prefer to convert the tubers into more stable forms such as chips and flours so as to prolong the shelf life (Ayinde and Dinrifo, 2001; Oyewole, 2002). Furthermore, the development of value-added products from Anchote flour could increase opportunities to expand the utilization of Anchote and help to improve the economy of various Anchote-producing areas. According to some scientific research, traditional processing of Anchote will improve palatable and digestibility of Anchote than that of raw Anchote but, boiling of Anchote during traditional processing would cause nutrition losses (Habtamu et al., 
2013). However, limited researches or no information is available on the functional properties of the Anchote flour that would affect Anchote products quality.

Cookies are convenient snacks product dried to a very low moisture content, which is taken among young people and adult to provide energy. Traditionally, cookies are made from wheat flour but small quantities of other cereal flours or starches can also be added to give special flavor or structural properties. In recent years, the interest in high fiber content in foods has greatly increased. High dietary fiber supplemented cookies have been prepared by replacing wheat flour with cereal by-products and tuber crops (Sudha et al., 2007). Considering the nutritional status of Anchote, it has more than twice of the protein, ash and dietary fiber content that of root crops and containing high amounts of calcium, potassium and iron (Habtamu and Kelbessa, 1997; Habtamu, 2011).

Baking is a complicated process and optimum conditions vary with the type of food being prepared and even with specific formula within the food type (Xue and Walker, 2003). Moreover, Baik et al. (2000) mentioned that final product properties are not only affected by the formulation (choice and quantity of ingredients), but also by processing conditions. Basically, processing conditions affect starch and protein properties and hence the food's quality. It resulted from the heat that is being transferred into the food causing changes in protein denaturation and starch gelatinization both within the product and its surface. Baking time and temperature highly influence heat transfer and the quality of a baked product, due to complex physicochemical interactions that occur between the ingredients, leading to the difference, primarily in texture, aroma and color of the products (Shibukawa et al., 1989).

Anchote being among few indigenous vegetable crops in Ethiopia that has been historically given low attention in terms of research as well as production is not well developed and popularized, despite its food and nutrition security and other functional potentials (Habtamu et al., 2013). Anchote is a perishable item with a high content of moisture and carbohydrate that facilitates microbial growth, which requires the removal of moisture during processing. In addition, the substitution of Anchote flour to wheat flour for cookies making is an important avenue toward economic utilization of this crop and can be important for celiac diseases prevention due to the fact that Anchote is gluten -free tuber crop. Thus, studying the characteristics of Anchote flour and analyzing the physical quality of Anchote composite flour cookies is important. Due to this the present study was, therefore, mainly envisaged with the objective of investigating wheat - Anchote (Coccinia abyssinica (Lam.)) composite flours for cookies production.

\section{Materials and methods}

\subsection{Experimental material}

The Anchote used for this study was procured within $24 \mathrm{hrs}$ of harvest from Nekemte farm gate market. Wheat (Triticum astivum L.) grain of variety "Hawi" was procured from Kulumsa Agricultural Research Center. Other ingredients such as salt, sugar, margarine, baking powder and eggs were purchased from local markets nearby Haramaya University. Anchote preparing and drying were performed at Wollega University in Food Science and Nutrition Laboratories. Cookies preparation and sensory evaluation were carried out at Haramaya University in Food Science and Central Laboratories.

\subsection{Experimental design}

The experiment consisted of two factors: three blending ratios and three baking temperatures as shown in Table 1. Whole wheat flour sample was taken as a control. The experiment was done in a completely randomized design (CRD) for preparing cookies samples. The treatments were run in three replications.

Table 1. Experimental layout

\begin{tabular}{cccc}
\hline Factor 1 & \multicolumn{3}{c}{ Factor 2 (Baking Temperature) } \\
(Blending Ratio) & $\mathrm{T}_{1}$ & $\mathrm{~T}_{2}$ & $\mathrm{~T}_{3}$ \\
\hline $\mathrm{B}_{1}$ & $\mathrm{~B}_{1} \mathrm{~T}_{1}$ & $\mathrm{~B}_{1} \mathrm{~T}_{2}$ & $\mathrm{~B}_{1} \mathrm{~T}_{3}$ \\
$\mathrm{~B}_{2}$ & $\mathrm{~B}_{2} \mathrm{~T}_{1}$ & $\mathrm{~B}_{2} \mathrm{~T}_{2}$ & $\mathrm{~B}_{2} \mathrm{~T}_{3}$ \\
$\mathrm{~B}_{3}$ & $\mathrm{~B}_{3} \mathrm{~T}_{1}$ & $\mathrm{~B}_{3} \mathrm{~T}_{2}$ & $\mathrm{~B}_{3} \mathrm{~T}_{3}$ \\
$\mathrm{C}$ & $\mathrm{CT}_{1}$ & $\mathrm{CT}_{2}$ & $\mathrm{CT}_{3}$ \\
\hline
\end{tabular}

$\mathrm{W}=$ Control (wheat flour $100 \%), \mathrm{B}_{1}=90 \%$ wheat flour and $10 \%$ Anchote flour, $\mathrm{B}_{2}=85 \%$ wheat flour and $15 \%$ Anchote flour, $\mathrm{B}_{3}=80 \%$ wheat flour and $20 \%$ Anchote flour. $\mathrm{T}_{1}=160^{\circ}$ $\mathrm{C}, \mathrm{T}_{2}=180^{\circ} \mathrm{C}, \mathrm{T}_{3}=200^{\circ} \mathrm{C}$

\subsection{Preparation of Anchote flour}

Anchote flour was prepared according to Habtamu et al. (2013) method as shown in Figure 1. The selected tubers were peeled using a sharp stainless-steel knife and sliced using a slicer to obtain a thickness of $6 \mathrm{~mm}$; the sliced product was washed in water and placed on a sieve to remove excess water. It was then dried in cabinet oven dryer (Memmert, model 765 , Germany) at $50^{\circ} \mathrm{C}$ with a constant circulating air velocity for 24 hrs. After drying, the material was pulverized separately using a laboratory hammer mill (Nima, model NM8300, Japan) and sieved through a $350 \mu \mathrm{m}$ size screen to obtain flour with uniform particle sizes. The flour samples were separately packaged in polyethylene bags until used for analysis 
and stored at room temperature.

\subsection{Preparation of wheat flour}

Whole wheat flour was obtained by cleaning and removing dirt, stones and other extraneous materials and then the husk was removed. The flour was milled by laboratory miller (Model 3510-011p Collins, USA). The flour was then sieved through a $350 \mu \mathrm{m}$ sieve size to obtain fine flour. The flour was sealed in a polyethylene bag and stored at room temperature (Peter et al., 2017) as shown in Figure 1.

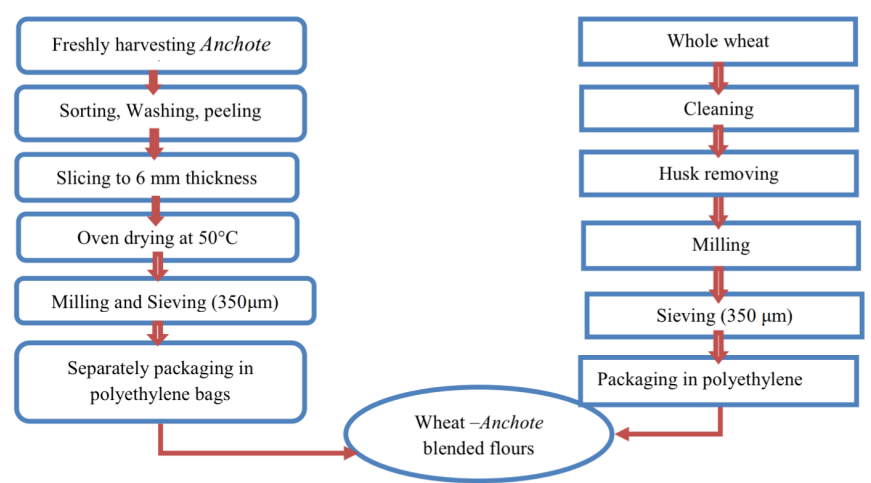

Figure 1. Flow chart for preparation of Anchote flour (Habtamu, 2013) and wheat flour

2.5 Determination of physical properties of wheat, Anchote and composite flours

\subsubsection{Particle size distribution}

The particle size distribution of flour samples obtained from the blends of wheat and Anchote flour was carried out using a sieve analysis technique as described by Lesego (2014) using the following formula:

$$
\% \text { Recovered }=\frac{\mathrm{W}_{\text {seive }}}{\mathrm{W}_{\text {total }}} \times 100
$$

Where $\mathrm{W}_{\text {sieve }}$ is the weight of the aggregate in the sieve, and $\mathrm{W}_{\text {total }}$ is the weight of the total aggregate.

\subsubsection{Angle of repose}

The angle of repose was the angle formed by the horizontal base of a pile of flour and the inclined surface of a cone-like pile of flour and calculated by (Jan et al., 2015) using the following relations

$$
\text { Angle of Repose }\left(\phi^{\circ}\right)=\tan ^{-1}\left(\frac{2 h}{d}\right)
$$

Where $\Phi=$ angle of repose $\left(^{\circ}\right) ; \mathrm{h}=$ height of the heap $(\mathrm{mm})$; and $\mathrm{d}=$ diameter of the base of the heap $(\mathrm{mm})$

\subsubsection{Bulk density}

The bulk density of the flour samples was determined according to the method of Giami et al. (1992) by using the following formula.

$$
\text { Bulk density }(\mathrm{g} / \mathrm{mL})=\frac{\text { Weight of sample used }}{\text { Volume of sample after tapping }}
$$

2.6. Determination of functional properties of wheat, Anchote and composite flours

\subsubsection{Water absorption capacity}

Water absorption capacity was determined by the method of Sze and Sathe (2000) using the following formula. Water-holding capacity was expressed as gram of water held per gram of flour sample.

$$
\text { Water absorption capacity }(\mathrm{g} / \mathrm{g})=\frac{\mathrm{W}_{3}-\mathrm{W}_{2}}{\mathrm{~W}_{1}}
$$

Where $\mathrm{W}_{3}$ is the weight of empty tube and sample after centrifuged and decanted; $\mathrm{W}_{2}$ is the weight of empty tube and sample before centrifuging; and $\mathrm{W}_{1}$ is the weight of sample.

\subsubsection{Oil absorption capacity}

Oil absorption capacity (OAC) was determined using the method of AOAC (2000) using the following formula:

$$
\text { Oil Absorption Capacity }(\mathrm{mL} / \mathrm{g})=\frac{V_{1}-V_{2}}{W_{0}}
$$

\subsubsection{Swelling power}

Swelling power and solubility determinations was carried out in the temperature range of $60-90^{\circ} \mathrm{C}$ using the method of Leach et al. (1959) by the following formula:

$$
\begin{aligned}
& \text { Swelling power (\%) }=\frac{\text { Wt of sedment }}{\text { Sample wt }- \text { Wt of soluble }} \\
& \text { Solubility Index }(\%)=\frac{\text { Wt of dryed supernatant }}{\text { Wt of sample }} \times 100
\end{aligned}
$$

\subsubsection{Dispersibility}

Dispersibility was determined using the method described by AACC (2000). Flour sample of $10 \mathrm{~g}$ was weighed into $100 \mathrm{~mL}$ measuring cylinder and water was added to reach the volume of $100 \mathrm{~mL}$. The set up was stirred vigorously and allowed to stand for three hours. The volume of settled particles was recorded and subtracted from 100. The differences reported as percentage dispersibility.

$\%$ Dispersibility $=100-$ Volume of settled particle

\subsection{Cookie Preparation}

Cookies were prepared according to the method of Manley (1998). Flour about (100 g) from each sample of different flour blends, margarine (10 g), sugar (2 g), baking powder $(1 \mathrm{~g})$, egg $(50 \mathrm{~g})$, salt $(1 \mathrm{~g})$ and $50 \mathrm{~mL}$ of water was added. The dry ingredients (composite flour, sugar, salt and baking powder) were mixed until uniform mixtures of the ingredients were obtained. The egg was added and the mixtures were kneaded. The dough was rolled on a floured board using a rolling pin to a thickness of $0.50 \mathrm{~cm}$. The rolled batter was cut into 
circular shapes with cookies of $5.5 \mathrm{~cm}$ diameter and arranged on a greased tray and baked at different temperature. The baking temperature for Anchote composite flour cookies was tested at different temperatures of $\left(160^{\circ} \mathrm{C}, 180^{\circ} \mathrm{C}\right.$ and $\left.200^{\circ} \mathrm{C}\right)$ at a constant time (20 mins). The cookies were cooled at ambient temperature for 30 mins and packaged in polyethylene bag until used for laboratory analysis.

\subsection{Physical analysis of cookies}

\subsubsection{Spread ratio}

Diameter and thickness were measured with a ruler at three deferent places in each cookie and the average was calculated for each. The average of six cookies was recorded for each batch. In order to determine the cookie, the spread ratio (SR) was calculated using the following equation (Chauhan et al., 2015):

$\mathrm{SR}=$ Diameter of cookies $/$ Thickness of cookies

\subsubsection{Specific volume of the cookies}

The specific volume (SV) of the cookies was determined by the seed displacement method (AACC 2000) $2 \mathrm{hrs}$ after baking was done. In order to find the specific volume of the cookies, first, the cookie was weighed and then placed into a container, which had a known volume. Then, the rape seeds were added, and the tapping process began. After tapping, the container filled with the cookie and rape seeds were re-weighed. If the different value read, more rape seeds were added, and the surface was smoothed by the help of a ruler. The same procedure continued until a constant weight was measured. The bulk density of the rape seeds was measured by the same procedure and calculated as 0.665 $\mathrm{g} / \mathrm{cm}^{3}$. The volume of the cookies was calculated:

$\mathrm{W}_{\text {seeds }}=\mathrm{W}_{\text {total }}-\mathrm{W}_{\text {cookies }}-\mathrm{W}_{\text {container }}$

$\mathrm{V}_{\text {seeds }}=\mathrm{W}_{\text {seeds }} / \rho_{\text {seeds }}$

$\mathrm{V}_{\text {cookie }}=\mathrm{V}_{\text {container }}-\mathrm{V}_{\text {seeds }}$

Where $\mathrm{W}$ represents the weight $(\mathrm{g}), \mathrm{V}$ is the volume $\left(\mathrm{cm}^{3}\right)$; and $\rho$ is the density $\left(\mathrm{g} / \mathrm{cm}^{3}\right)$. The specific volume was calculated by dividing the volume of the cookies by its weight;

$\mathrm{SV}_{\text {cookie }}=\mathrm{V}_{\text {cookie }} / \mathrm{W}_{\text {cookie }}$

\subsubsection{Textural profile analysis (hardness)}

The textural characteristics of the cookies were determined by Pareyt et al. (2008) using textural analyzer (Stable Micron Systems TA.XT plus, USA). In this test, two beams at a known distance support the product. A third beam was brought down through the product at a point equidistant from both support beams. With a blade ( $70 \mathrm{~mm}$ wide and $3 \mathrm{~mm}$ thick), a downward movement of the top beam was exerted until the product breaks. A texture analyzer, with the $50 \mathrm{~N}$ load cells, was used to measure the force needed for cookie hardness analysis in compression mode. The cookies were analyzed at a test speed of $70 \mathrm{~mm} / \mathrm{min}$. The maximum force required to break a single cookie was recorded and the average value of 10 cookies for each batch recorded.

\subsubsection{Color measurement.}

The color values of the cookies were measured in three different zones of the crust using a digital spectrophotometer Mini Scan EZ (Model: Cr-10 Minolta, Japan), which was provided with the software. A chromometer was calibrated with the standard black and white color. The results were the averages of three measurements using CIELAB $L^{*} ; a^{*}$ and $b^{*}$ values. $L^{*}$ value is the lightness variable from 100 for perfect white to zero for black; while $\mathrm{a}^{*}$ and $\mathrm{b}^{*}$ values are the chromaticity values, +redness/-greenness and +yellowness/blueness, respectively (Palatnik et al., 2015). Whiteness Index (WI) for each sample was calculated according to the following equation (Zhu et al., 2009).

$$
\begin{aligned}
& \text { Chroma }\left(\mathrm{C}^{*}\right)=\sqrt{a^{* 2}+b^{* 2}} \\
& \text { Hue }\left(\mathrm{h}^{*}\right)=\tan ^{-1} \frac{b^{*}}{a^{*}} \\
& \mathrm{WI}=100-\left[\left(100-\mathrm{L}^{*}\right)^{2}+\mathrm{a}^{* 2}+\mathrm{b}^{* 2}\right]^{1 / 2}
\end{aligned}
$$

The total color change, $\Delta E$ of the cookies from the reference is:

$\Delta E=\left(\left(\mathrm{L}_{0}-\mathrm{L}\right)^{2}+\left(\mathrm{a}_{0}-\mathrm{a}\right)^{2}+\left(\mathrm{b}_{0}-\mathrm{b}\right)^{2}\right)^{1 / 2}$

Where $\mathrm{L}_{0}=100, \mathrm{a}_{0}=0$ and $\mathrm{b}_{0}=0$

\subsection{Sensory evaluation}

The sensory evaluation was carried out using 7-point hedonic scale according to (Lawless and Heymann, 1999).The sensory assessments were conducted by 30 panelists, who had been randomly selected from Haramaya University Department of Food Technology and Process Engineering with no addiction problem. They were requested to evaluate sensory attributes such as visual color, taste, aroma, crispiness and overall acceptability of the cookies. Orientations were given to the panelists on the procedure of sensory evaluation and instructed to rinse their mouth with water after tasting each cookies sample.

\subsection{Statistical data analysis}

All the data collected were analyzed using analysis of variance (ANOVA) using SAS 9.1 software package (SAS Institute Inc., Cary, NC). The differences between means were compared using Fisher's least significant difference (LSD) at a probability level of $5 \%$. 


\section{Results and discussion}

3.1 Physical properties of wheat, Anchote and composite flours

Physical properties of granular solids play a significant role in their flow behavior and storage and thus are essential to design appropriate, efficient, economic bulk handling and storage equipment.

\subsubsection{Moisture content}

The moisture content of Anchote and wheat flour were $7.68 \%$ and $10.78 \%$ respectively on wet basis with significant $(p<0.05)$ difference between them (Table 2). Similar findings were reported by Habtamu (2011) and Demelash (2016) were the moisture content value of Anchote flour was 9.78 and $7.28 \%$ respectively. Composite flours of 10, 15 and 20\% of Anchote had moisture content values 10.33, 9.77 and $9.00 \%$, respectively, with a significant $(p<0.05)$ difference between the highest and the lowest values. This can be explained by the fact that Anchote flour contained less water $(7.68 \%)$. This result was in line with the findings reported by Temesgen et al. (2015), there was a decrease in the moisture content with increase the proportion of orange fleshed sweet potato (OFSP) flour in wheat orange fleshed sweet potato composite flours, which was attributed to the less moisture content of OFSP $(7.36 \%)$ than soft wheat flour $(10.5 \%)$. The decrease in moisture level with an increase in the level of substitution might serve as an indication of increasing storage stability of the composite flours. The lower moisture contents of composite flours implied better shelf life and denser nutrient composition.

\subsubsection{Crude fiber}

The mean values of crude fiber content for wheat and Anchote flour were $0.85 \%$ and $2.93 \%$ respectively with significant $(p<0.05)$ difference between them (Table $2)$. There were significant $(p<0.05)$ differences in the crude fiber content for composite flours due to various blending ratios. The crude fiber content of the composite flours increased from $0.85 \%$ in control whole wheat flour sample to $0.99,1.17$ and $1.38 \%$ in the composite flours with the increase in ratio of Anchote in the order of 10,15 and $20 \%$, respectively. Similarly, result was reported by previous researcher Demelash (2016), showing the fiber content increment with increasing substitution level of Anchote flour in wheat-Anchote composite flours for bread making. According to the author, Anchote tuber was relatively higher in both ash and fiber content. Also, this study was in line with the finding reported by Abebe et al. (2018), who showed that the fiber content increased with increasing level of incorporation of Anchote flour in wheat-Anchotesoybean composite flours.

The values of the fiber content of Anchote flour in this study agreed with the findings reported by Habtamu (2014), who noticed comparable crude fiber content (2.58\%) but, much higher than $1.7 \%$ reported by Agren and Gibson (1969). Also, other study was reported by Beruk et al. (2015) the crude fiber contents were between 4.28 - $8.91 \%$ in Dicho accessions grown in Hawassa and Wondo Genet and $3.94 \%$ as indicated by Abebe et al. (2018). Crude fiber is derived from tuber extractions and may vary in a greater extent due to the techniques and sieves that used for the removal of fibrous material.

\subsubsection{Angle of repose}

The mean values of Angle of repose were $31.23^{\circ}$ for Anchote and $37.93^{\circ}$ for wheat flour with significant $(p<0.05)$ difference among them (Table 2). Ogunsana et al. (2016) reported that the angle of repose for cassava, white yam and cocoyam flours were in the range from $31.43^{\circ}$ to $32.94^{\circ}$, while for sorghum and wheat it was 39.65 and $38.83^{\circ}$, respectively. These results indicate that root and tuber crop flour have a lower angle of repose than cereal flours.

The angle of repose of the composite flours significantly $(p<0.05)$ decreased as the Anchote flour incorporation increased in composite flours. The values of angle of repose reduced to $37.49,36.14$ and $35.96^{\circ}$ as the Anchote blending ratio increased to 10,15 and $20 \%$, respectively. This was due to the fact that Anchote flour had a higher proportion (65\%) of larger particle size $(\geq 150 \mu)$ and lower moisture content $(7.68 \%)$ than wheat

Table 2. Physical properties of wheat, Anchote and composite flours

\begin{tabular}{ccccc}
\hline Treatments & Moisture $(\mathrm{wb} \%)$ & Crude Fiber $(\%)(\mathrm{wb} \%)$ & Angle Repose $\left(^{\circ}\right)$ & Bulk Density $(\mathrm{g} / \mathrm{mL})$ \\
\hline $\mathrm{W}$ & $10.78 \pm 0.84^{\mathrm{a}}$ & $0.85 \pm 0.01^{\mathrm{e}}$ & $37.93 \pm 0.37^{\mathrm{a}}$ & $0.66 \pm 0.01^{\mathrm{d}}$ \\
$\mathrm{A}$ & $7.68 \pm 0.50^{\mathrm{d}}$ & $2.93 \pm 0.01^{\mathrm{a}}$ & $31.23 \pm 0.59^{\mathrm{d}}$ & $0.82 \pm 0.02^{\mathrm{a}}$ \\
$\mathrm{B}_{1}$ & $10.33 \pm 0.00^{\mathrm{ab}}$ & $0.99 \pm 0.09^{\mathrm{d}}$ & $37.49 \pm 1.10^{\mathrm{ab}}$ & $0.68 \pm 0.01^{\mathrm{cd}}$ \\
$\mathrm{B}_{2}$ & $9.77 \pm 0.50^{\mathrm{bc}}$ & $1.17 \pm 0.03^{\mathrm{c}}$ & $36.14 \pm 1.07^{\mathrm{bc}}$ & $0.70 \pm 0.01^{\mathrm{c}}$ \\
$\mathrm{B}_{3}$ & $9.00 \pm 0.33^{\mathrm{c}}$ & $1.38 \pm 0.05^{\mathrm{b}}$ & $35.96 \pm 0.62^{\mathrm{c}}$ & $0.73 \pm 0.01^{\mathrm{b}}$ \\
\hline $\mathrm{LSD}$ & 0.93 & 0.09 & 1.47 & 0.03 \\
CV\% & 5.53 & 3.43 & 2.26 & 2.52 \\
\hline
\end{tabular}

Values are expressed as means \pm SD. Values in the same column with different superscript letters are significantly different from each other $(\mathrm{p}<0.05)$. 
flour. Higher moisture content reduces movement of particles, hence flow of particulate materials leading to a greater angle of repose and vice versa. Smaller particle size results in more contact surface area thus more friction between particles leading to a larger angle of repose and vice versa. A comparable result was observed by Mateusz et al. (2013) that compared the angle of repose for maize starch $\left(36^{\circ}\right)$, wheat starch (from 42 to $\left.56^{\circ}\right)$ and potato starch $\left(33.65^{\circ}\right)$ flour. The larger particle size of the potato starch resulted in less angle of repose. Additionally, Jan et al. (2015) finding reported the angle of repose for commercial rice flour was found to be $66.57^{\circ}$. For this reason, the parameter is important in proper design of hoppers to maintain the continuous flow of the rice flour, which must be larger than the angle of repose of rice flour. The angle of repose above $50^{\circ}$ is an indication of poor flow characteristics of powder (Adebayo and Itiola, 2003).

\subsubsection{Bulk density}

Bulk density mean values were $0.66 \mathrm{~g} / \mathrm{mL}$ for wheat flour and $0.82 \mathrm{~g} / \mathrm{mL}$ for Anchote flour with significance $(p<0.05)$ differences between them (Table 2). The recorded bulk density values of the composite flours were $0.68,0.70$ and $0.73 \mathrm{~g} / \mathrm{mL}$ for Anchote blending ratios of 10,15 and $20 \%$, respectively, with significance $(p<0.05)$ difference between the highest and the lowest values. This was due to the higher $(0.82 \mathrm{~g} / \mathrm{mL})$ bulk density of the Anchote flour. According to findings reported by Habtamu (2013), the bulk density value of Anchote flour ranged from 0.73 to $0.83 \mathrm{~g} / \mathrm{mL}$. This variation in bulk density outcome between different treatments of the flour was due to the bulk density of flours are affected by the particle size and density of the flour (Ajanaku et al., 2012). Flours with high bulk density have been known to be good for mixing purposes whereas those with lower bulk density may find a better usage in the baby food industry. Low bulk density of the flours may be considered advantageous when determining transportation cost and space requirement; as less space will be required for packaging of the flours.

\subsection{Functional properties of wheat, Anchote and composite flours}

\subsubsection{Water absorption capacity (WAC)}

Table 3 depicts the water absorption capacity data of wheat, Anchote and their composite flours. The water absorption capacity values were $1.84 \mathrm{~g} / \mathrm{g}$ for wheat and $2.44 \mathrm{~g} / \mathrm{g}$ for Anchote flour with a significant $(p<0.05)$ difference between them. Earlier researcher Habtamu (2013) reported a comparable result for the WAC of Anchote flour, which ranged from 1.93 to $2.13 \mathrm{~g} / \mathrm{g}$ while, as a comparison, the WAC for sweet potato and cassava flour were $2.37 \mathrm{~g} / \mathrm{g}$ and $1.66 \mathrm{~g} / \mathrm{g}$ respectively (Eriksson et al., 2014; Ehimen et al., 2017).

As the blending ratio of Anchote flour increased for the composite flours, from 10,15 and $20 \%$ the WAC values increased from 1.86, 2.04 and $2.13 \mathrm{~g} / \mathrm{g}$, respectively, with a significant $(p<0.05)$ difference between the highest and the lowest values. This could indicative of the fact that addition of Anchote flour to wheat flour confers high water binding capacity to the composite flour, which in turn improves the reconstitution ability (Ajanaku et al., 2012) and textural properties of dough obtainable from wheat-Anchote composite flours. The same trend for WAC was reported by Eriksson et al. (2014), who showed that as the substitution level of cassava flour increased the water holding capacity of wheat-cassava composite flours increased. According to Adetuyi et al. (2009), the flour with higher water absorption capacity could be used as thickener in liquid and semi-liquid foods since the flour has the ability to absorb water and swell for improved consistency in food. Hence, the Anchote flour has high water holding capacity it is best to select as raw material for the bakery products and others.

\subsubsection{Oil absorption capacity $(O A C)$}

The values of oil absorption capacity were $1.92 \mathrm{~mL} /$ $\mathrm{g}$ for Anchote and $2.18 \mathrm{~mL} / \mathrm{g}$ for wheat with a significant $(p<0.05)$ difference between them. Significant $(p<0.05)$ differences were also observed in OAC of the composite flours due to various blending ratios. The values for the composite flours decreased from $2.18 \mathrm{~mL} / \mathrm{g}$ for whole wheat flour sample to $2.14,2.10$ and $2.08 \mathrm{~mL} / \mathrm{g}$ in the composite flours with the increase in the ratio of Anchote flour in the order of 10,15 and $20 \%$, respectively. The higher the oil absorption capacity of a flour sample, the better the cookie quality. The same trend pattern was reported by Adeleke and Odedeji (2010) who showed that the fat absorption capacity decreased as more and more sweet potatoes was incorporated in wheat - sweet potato composite flours, indicating the diluting effect of sweet potato flour on wheat flour fat absorption capacity. Oil absorption index was important since oil acts as flavor retainer and increases the mouth feel of foods, improvement of palatability and extension of shelf life particularly in the bakery where fat absorptions are desired (Julianti et al., 2015).

\subsubsection{Swelling power of flours}

The mean values were $9.08 \mathrm{~g} / \mathrm{g}$ for wheat and 11.48 $\mathrm{g} / \mathrm{g}$ for Anchote flour with significant $(p<0.05)$ difference between the two. The high swelling power of Anchote flour could be in fact attributed to its low protein and high carbohydrate content; hence, swelling power of flours is often related to their protein and starch contents 
(Woolfe, 1992). A similar finding was reported by Habtamu (2013), which ranged from 9.36 to $12.58 \mathrm{~g} / \mathrm{g}$. As a comparison, the swelling power of cassava flour was 7.38 to $12.04 \%$ as reported by Eriksson et al. (2014), swelling power values of starches from rice cultivar were in the range of 2.11 to $3.68 \%$ and swelling power of wheat flour were in the range of 7.5 to $10.8 \%$ (Ashogbon and Akintayo, 2012).

In case of the composite flour, there was no significant $(p>0.05)$ differences observed among the values of the three composite flours and yet numerically the values increased with increase in Anchote blending ratio. The higher the substitution levels the higher the rate at which the flour swell. Similar trend result was reported by earlier researcher Eriksson et al. (2014) who showed that the swelling power of blended flours increased with increase cassava flour in wheat - cassava blended flours.

\subsubsection{Solubility}

The solubility values for the control sample and composite flours are displayed in Table 3 . The values were $35.87 \%$ for wheat flour and $41.53 \%$ for Anchote flour with a significant $(p<0.05)$ difference between them. According to a study reported by Habtamu (2013), the solubility values for Anchote flour ranged from 48.10 to $54.23 \%$. Also, Chiemela et al. (2013) showed that the solubility values ranged from 3.95 to $32.19 \%$ for cassava starch. In this study the solubility of the composite flours significantly $(p<0.05)$ increased as the Anchote flour incorporation increased in composite flours. The values increased to $36.75,37.33$ and $38.40 \%$ as the Anchote blending ratio increased to 10,15 and $20 \%$, respectively. High solubility implies high leaching. The solubility of the starch is believed to be affected by factors such as inter- associative forces, swelling power, presence of surfactants and other associative compounds (Sibanda and Sychawska, 2000). Flour with a very high solubility may result in a soggy and less cohesive dough when applied in baking.

\subsubsection{Dispersibility}

The dispersibility value for Anchote and wheat flour were 67.33 and $73.66 \%$, respectively, with significant $(p<0.05)$ difference from each other. For comparison, a similar result was reported by Ogunisina et al. (2016) who showed that the dispersibility for cassava, yam, maize and wheat were $69.00,65.00,68.1$ and $71.1 \%$, respectively. The dispersibility value for $100 \%$ wheat flour was higher than wheat-Anchote composite flours samples. The dispersibility of the composite flours indicated that the increase in the blending ratio of the Anchote flour resulted in a decreased dispersibility of the composite flours. Composite flours of 10, 15 and $20 \%$ Anchote had dispersibility values of $72.33,71.66$ and $70.00 \%$, respectively, with a significant $(p<0.05)$ difference between the highest and the lowest values. The same trend was reported by previous work of Oluwakemi et al. (2017) that showed that the dispersibility of composite flours decreased with increasing the ratio of high - quality cassava (HQCF) in wheat- HQCF-mushroom flour which ranged from 62.10 to $72.00 \%$. Dispersibility is an index of the ease of reconstitution of flour into a fine consistency paste during stirring (Adebowale et al., 2008). Flour dispersibility can also give an indication of particles suspensibility in water, which is a useful functional parameter in various food products formulations.

\subsection{Physical properties of cookies}

\subsubsection{Spread ratio}

The spread ratio is an important characteristic for determining the quality of cookies. The spread factors of cookies had significant $(p<0.05)$ differences due to blending ratio and baking temperature but no significant $(p>0.05)$ difference due to the interaction as shown in Table 4. The highest spread ratio 9.47 was for cookies with $20 \%$ Anchote and baked at $200^{\circ} \mathrm{C}$ and lowest values 7.99 for cookies prepared from whole wheat and baked at $160^{\circ} \mathrm{C}$. Both factors of the blending ratios and baking temperatures had an equal effect on the spread ratio of cookies.

Cookies with higher spread ratios are considered the

Table 3. Functional properties of wheat, Anchote and composite flours

\begin{tabular}{cccccc}
\hline Treatments & Water Absorption $(\mathrm{g} / \mathrm{g})$ & Oil Absorption $(\mathrm{mL} / \mathrm{g})$ & Swelling power $(\mathrm{g} / \mathrm{g})$ & Solubility $(\%)$ & Dispersibility (\%) \\
\hline $\mathrm{W}$ & $1.84 \pm 0.01^{\mathrm{c}}$ & $2.18 \pm 0.01^{\mathrm{a}}$ & $9.08 \pm 0.08^{\mathrm{c}}$ & $35.87 \pm 0.82^{\mathrm{d}}$ & $73.66 \pm 0.57^{\mathrm{a}}$ \\
$\mathrm{A}$ & $2.44 \pm 0.00^{\mathrm{a}}$ & $1.92 \pm 0.01^{\mathrm{e}}$ & $11.48 \pm 0.87^{\mathrm{a}}$ & $41.53 \pm 0.81^{\mathrm{a}}$ & $67.33 \pm 0.57^{\mathrm{d}}$ \\
$\mathrm{B}_{1}$ & $1.86 \pm 0.09^{\mathrm{c}}$ & $2.14 \pm 0.00^{\mathrm{b}}$ & $9.19 \pm 0.05^{\mathrm{bc}}$ & $36.75 \pm 0.81^{\mathrm{cd}}$ & $72.33 \pm 1.15^{\mathrm{ab}}$ \\
$\mathrm{B}_{2}$ & $2.04 \pm 0.06^{\mathrm{b}}$ & $2.10 \pm 0.01^{\mathrm{c}}$ & $9.58 \pm 0.15^{\mathrm{bc}}$ & $37.33 \pm 0.57^{\mathrm{bc}}$ & $71.66 \pm 1.52^{\mathrm{bc}}$ \\
$\mathrm{B}_{3}$ & $2.13 \pm 0.04^{\mathrm{b}}$ & $2.08 \pm 0.01^{\mathrm{d}}$ & $9.83 \pm 0.16^{\mathrm{b}}$ & $38.40 \pm 0.35^{\mathrm{b}}$ & $70.00 \pm 1.00^{\mathrm{c}}$ \\
\hline LSD & 0.12 & 0.02 & 0.73 & 1.27 & 1.87 \\
CV\% & 3.39 & 0.64 & 4.10 & 1.84 & 2.14 \\
\hline
\end{tabular}

Values are expressed as means \pm SD. Values in the same column with different superscript letters are significantly different from each other $(\mathrm{p}<0.05)$. 
most desirable (Ayo et al., 2007). The increase in the spread ratio could be attributed to the increased number of hydrophilic sites in the dough mixture leading to increased water absorption and swelling index. This may be due to the higher fiber and solid matter content and also high-water holding capacity of the Anchote flour. The similar trend increment was reported by Olapade and Adeyemo (2014) that showed that the spread ratio of the composite flours increased with increase the substitution of cassava flour in wheat - cassava - cowpea composite flours cookies.

Table 4. Effect of interaction of Anchote blending and baking temperature interaction on the physical property of cookies.

\begin{tabular}{cccc}
\hline Code & Spread ratio & Specific volume $\left(\mathrm{cm}^{3} / \mathrm{g}\right)$ & Hardness $(\mathrm{N})$ \\
\hline $\mathrm{WT}_{1}$ & $7.99 \pm 0.15^{\mathrm{c}}$ & $2.03 \pm 0.02^{\mathrm{a}}$ & $4.13 \pm 0.02^{\mathrm{i}}$ \\
$\mathrm{WT}_{2}$ & $8.06 \pm 0.09^{\mathrm{bc}}$ & $1.92 \pm 0.01^{\mathrm{b}}$ & $5.98 \pm 0.25^{\mathrm{h}}$ \\
$\mathrm{WT}_{3}$ & $8.07 \pm 0.13^{\mathrm{bc}}$ & $1.68 \pm 0.04^{\mathrm{de}}$ & $9.00 \pm 0.37^{\mathrm{g}}$ \\
$\mathrm{B}_{1} \mathrm{~T}_{1}$ & $8.01 \pm 0.02^{\mathrm{bc}}$ & $1.98 \pm 0.01^{\mathrm{ab}}$ & $6.56 \pm 0.39^{\mathrm{h}}$ \\
$\mathrm{B}_{1} \mathrm{~T}_{2}$ & $8.37 \pm 0.06^{\mathrm{abc}}$ & $1.82 \pm 0.09^{\mathrm{c}}$ & $9.13 \pm 0.40^{\mathrm{g}}$ \\
$\mathrm{B}_{1} \mathrm{~T}_{3}$ & $8.50 \pm 0.16^{\mathrm{abc}}$ & $1.70 \pm 0.05^{\mathrm{de}}$ & $11.51 \pm 0.12^{\mathrm{e}}$ \\
$\mathrm{B}_{2} \mathrm{~T}_{1}$ & $8.61 \pm 0.36^{\mathrm{abc}}$ & $1.75 \pm 0.05^{\mathrm{cd}}$ & $10.52 \pm 0.14^{\mathrm{f}}$ \\
$\mathrm{B}_{2} \mathrm{~T}_{2}$ & $8.93 \pm 0.14^{\mathrm{ab}}$ & $1.71 \pm 0.04^{\mathrm{de}}$ & $11.52 \pm 0.98^{\mathrm{e}}$ \\
$\mathrm{B}_{2} \mathrm{~T}_{3}$ & $9.24 \pm 0.27^{\mathrm{ab}}$ & $1.58 \pm 0.06^{\mathrm{f}}$ & $14.25 \pm 0.81^{\mathrm{d}}$ \\
$\mathrm{B}_{3} \mathrm{~T}_{1}$ & $8.88 \pm 0.60^{\mathrm{ab}}$ & $1.73 \pm 0.08^{\mathrm{cd}}$ & $16.95 \pm 0.13^{\mathrm{b}}$ \\
$\mathrm{B}_{3} \mathrm{~T}_{2}$ & $9.45 \pm 0.18^{\mathrm{a}}$ & $1.63 \pm 0.04^{\mathrm{ef}}$ & $15.71 \pm 0.65^{\mathrm{c}}$ \\
$\mathrm{B}_{3} \mathrm{~T}_{3}$ & $9.47 \pm 0.34^{\mathrm{a}}$ & $1.56 \pm 0.07^{\mathrm{f}}$ & $19.98 \pm 0.16^{\mathrm{a}}$ \\
\hline $\mathrm{LSD}$ & 0.97 & 0.09 & 0.79 \\
\hline
\end{tabular}

Values are expressed as means \pm SD. Values in the same column with different superscript letters are significantly different from each other $(\mathrm{p}<0.05)$.

\subsubsection{Specific volume of the cookies}

The results of the effect of blending ratio and baking temperature on specific volume are presented in Table 4. The specific volume was significantly $(p<0.05)$ affected by the blending ratio, baking temperature and their interaction. The specific volume of the composite cookies decreased as the substitution level of Anchote flour increased. This could be due to the presence of high fiber content in the Anchote flour, which might interfere in the structure of the matrix, diminishing the gas retention capacity in the dough and due to low protein (gluten) content in Anchote replaced. This study was in line with the study conducted by Jemziya and Mahendran (2015), who stated that as substitution level of sweet potato flour increased in wheat-sweet potato composite cookies the specific volume of samples would decrease.

The specific volume values for control cookies exhibiting significant higher $\left(2.09\right.$ to $\left.1.68 \mathrm{~cm}^{3} / \mathrm{g}\right)$ as compared to the lower values $\left(1.73\right.$ to $\left.1.56 \mathrm{~cm}^{3} / \mathrm{g}\right)$ having $20 \%$ Anchote flour. It can be seen that the
Anchote blend reduced the gluten content, which makes gas retention in the dough. Similarly, the specific volume of cookies decreases as the baking temperature of cookies increased. The specific volume of cookies was equally influenced by both factors.

\subsubsection{Textural profile (hardness)}

The breaking strength refers to the force required to break the cookies. Hardness is measured by peak force to break the cookie. The breaking force was found to be an indicator of the crispness of cookies. Lower breaking force corresponds to higher crispness while the greater breaking strength indicates the greater hardness of cookies structure (Anis et al., 2014). The hardness of cookies was highly significantly $(p<0.05)$ different due to various blending ratio, baking temperature and their interaction. However, increasing the substitution ratio of Anchote resulted in increased hardness of cookies. This increment in hardness and fracturability during increasing replacement level of Anchote flour in composite flours may be due to the lesser fat content of Anchote than that of wheat and also the fiber content in Anchote flour would compact the structure of the dough. Similar, results were also reported by Singh et al. (2011) who stated that high-fat content increases brittleness due to migration of moisture from the center to the surface that causes breakage. The hardness of cookies significantly $(p<0.05)$ increased as the baking temperature of cookies increased. This is maybe due to high baking temperature remove more amount of water from the cookies during baking.

\subsubsection{Colour of cookies}

Colour, certainly is an indispensable sensorial attribute for characterizing food and judging its quality. Color of the cookie samples, expressed in terms of tristimulus attributes, $\mathrm{L}^{*}, \mathrm{a}^{*}$ and $\mathrm{b}^{*}$ values, as presented in Table 5 and Figure 2.

The $L^{*}$ value which shows lightness of the products were significantly $(p<0.05)$ different due to blending ratio and baking temperatures. The interaction between blending ratios and baking temperatures did not bring significant $(p>0.05)$ difference on the $L^{*}$ values of cookies, as shown in Table 5. However, reduction in the values of $\mathrm{L}^{*}$ indicated that the composite cookies are not as white as those of the control sample. This study was in line with the study conducted by Chauhan et al. (2016), who showed that the $\mathrm{L}^{*}$ value for cookies made from wheat-amaranth composite flours decreased as the incorporation level of amaranth flour increased.

The baking temperatures also had significant $(p<0.05)$ effect on the lightness of the flour. This means 
the $\mathrm{L}^{*}$ value of blended flour cookies decreased as the baking temperature of the cookies increased. This may be attributed to the interaction of protein and sugar during baking resulting in a higher degree of Maillard reaction (Chefel et al., 1989), and caramelization which is a direct degradation of sugars due to high temperature.

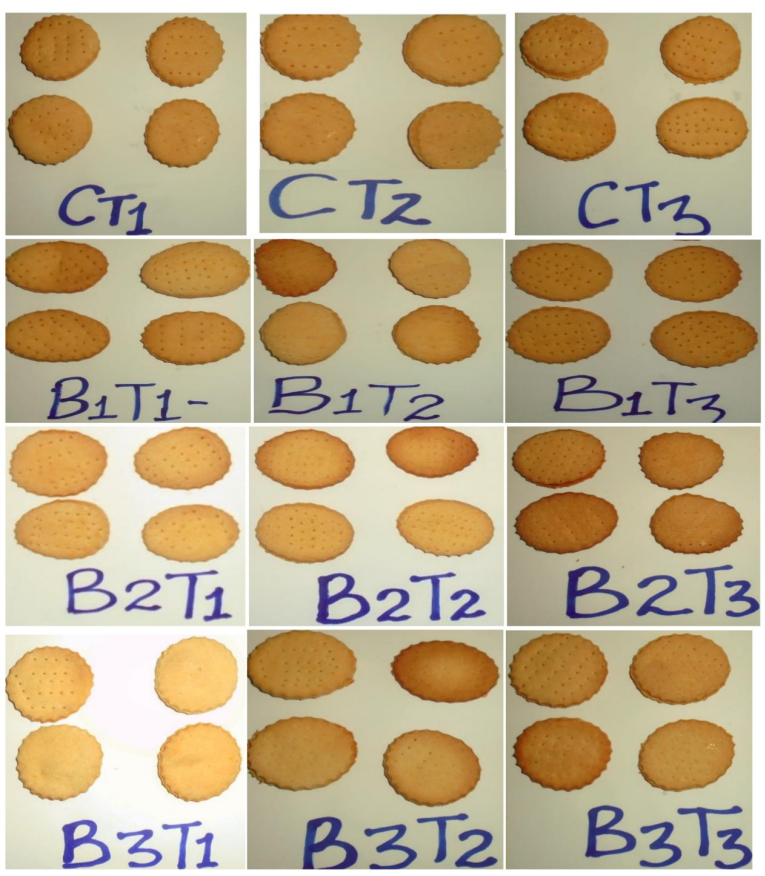

Figure 2. Wheat-Anchote cookies

The $\mathrm{a}^{*}$ values are indicative of the red or green color (positive value indicates red and negative value indicates green) and are shown in Table 5. The $\mathrm{a}^{*}$ was significantly $(p<0.05)$ affected by the blending ratio and baking temperature but, their interaction was not influenced. The $\mathrm{a}^{*}$ value of wheat-Anchote composite flours cookies increased as the incorporation level of Anchote flour increased. Similarly, the $\mathrm{a}^{*}$ value of the cookies increased as the baking temperatures of the cookies increased. The baking temperature were inversely proportional with the $\mathrm{L}^{*}$ value but, $\mathrm{a}^{*}$ and $\mathrm{b}^{*}$ values are directly proportional to baking temperature. This is mainly due to the fact that the rate of brown pigment formation increases with temperature (Das et al., 2012).

The $b^{*}$ color value indicates the yellow or blue colors (a positive value indicates yellow and negative value indicates blue) are shown in Table 5. The $b^{*}$ values were significantly $(p<0.05)$ different due to blending ratio, baking temperature and their interaction. The cookies containing Anchote flour had significantly $(p<0.05)$ higher $\mathrm{b}^{*}$ values than the control cookies. The $\mathrm{b}^{*}$ value of wheat-Anchote composite flours cookies increased as the baking temperature of the cookies increased. Generally, baking temperature exhibited a kind of domination during interaction with the blending ratio in that similar trend persisted among the cookies with different baking temperature. The $\mathrm{b}^{*}$ values ranged from 23.24 for cookies with whole Anchote and baked at $160^{\circ} \mathrm{C}$ to 28.65 for cookies with $20 \%$ Anchote and baked at $200^{\circ} \mathrm{C}$, with statistically $(p<0.05)$ difference between them.

Whiteness indices (WI) are widely measured to yield numbers correlating closely with consumers' preferences for white colors. The WI represents the overall whiteness of food products that may indicate the extent of discoloration during the drying process (Hsu et al., 2003). WI indicates the degree of whiteness. The recorded values of WI ranged from 67.64 to 73.77 , as shown in Table 5, with significant $(p<0.05)$ difference due to blending ratio, baking temperature and their interaction. The cookies having Anchote flour had lower WI than the control cookies. The WI of cookies decreased as the baking temperature increased.

Table 5. Effect of Anchote blend and baking temperature interaction on the color of cookies

\begin{tabular}{cccccc}
\hline Code & $\mathrm{L}^{*}$ & $\mathrm{a}^{*}$ & $\mathrm{~b}^{*}$ & $\mathrm{WI}$ & $\Delta \mathrm{E}$ \\
\hline $\mathrm{WT}_{1}$ & $66.24 \pm 0.74^{\mathrm{a}}$ & $10.64 \pm 0.78^{\mathrm{c}}$ & $23.24 \pm 2.24^{\mathrm{c}}$ & $73.77 \pm 2.16^{\mathrm{a}}$ & $42.36 \pm 1.68^{\mathrm{d}}$ \\
$\mathrm{WT}_{2}$ & $65.20 \pm 0.94^{\mathrm{ab}}$ & $11.05 \pm 0.45^{\mathrm{bc}}$ & $26.00 \pm 1.57^{\mathrm{bc}}$ & $70.22 \pm 1.59^{\mathrm{bcd}}$ & $45.42 \pm 1.44^{\mathrm{d}}$ \\
$\mathrm{WT}_{3}$ & $63.75 \pm 1.91^{\mathrm{bc}}$ & $11.91 \pm 0.93^{\mathrm{bc}}$ & $26.20 \pm 0.54^{\mathrm{ab}}$ & $70.58 \pm 0.16^{\mathrm{bc}}$ & $46.29 \pm 1.48^{\mathrm{cd}}$ \\
$\mathrm{B}_{1} \mathrm{~T}_{1}$ & $64.25 \pm 1.07^{\mathrm{bc}}$ & $10.95 \pm 0.55^{\mathrm{bc}}$ & $25.58 \pm 0.17^{\mathrm{bc}}$ & $71.53 \pm 0.10^{\mathrm{ab}}$ & $45.30 \pm 0.93^{\mathrm{d}}$ \\
$\mathrm{B}_{1} \mathrm{~T}_{2}$ & $63.41 \pm 0.43^{\mathrm{bcd}}$ & $12.02 \pm 0.58^{\mathrm{bc}}$ & $26.30 \pm 0.87^{\mathrm{ab}}$ & $70.44 \pm 0.59^{\mathrm{bcd}}$ & $46.64 \pm 0.70^{\mathrm{bcd}}$ \\
$\mathrm{B}_{1} \mathrm{~T}_{3}$ & $63.90 \pm 0.13^{\mathrm{bc}}$ & $12.85 \pm 0.42^{\mathrm{ab}}$ & $27.25 \pm 0.70^{\mathrm{ab}}$ & $69.26 \pm 0.44^{\mathrm{bcd}}$ & $47.02 \pm 0.23^{\mathrm{bcd}}$ \\
$\mathrm{B}_{2} \mathrm{~T}_{1}$ & $64.33 \pm 1.21^{\mathrm{bc}}$ & $11.75 \pm 0.59^{\mathrm{bc}}$ & $26.33 \pm 0.28^{\mathrm{ab}}$ & $70.55 \pm 0.11^{\mathrm{bc}}$ & $45.86 \pm 1.00^{\mathrm{cd}}$ \\
$\mathrm{B}_{2} \mathrm{~T}_{2}$ & $63.88 \pm 0.47^{\mathrm{bc}}$ & $12.11 \pm 1.41^{\mathrm{abc}}$ & $27.01 \pm 0.68^{\mathrm{ab}}$ & $69.76 \pm 0.70^{\mathrm{bcd}}$ & $46.71 \pm 0.65^{\mathrm{bdc}}$ \\
$\mathrm{B}_{2} \mathrm{~T}_{3}$ & $63.46 \pm 1.0 \mathrm{~b}^{\mathrm{cd}}$ & $12.82 \pm 1.50^{\mathrm{ab}}$ & $28.46 \pm 0.56^{\mathrm{ab}}$ & $67.64 \pm 0.57^{\mathrm{d}}$ & $48.43 \pm 0.50^{\mathrm{ab}}$ \\
$\mathrm{B}_{3} \mathrm{~T}_{1}$ & $62.88 \pm 0.88^{\mathrm{cd}}$ & $11.99 \pm 1.63^{\mathrm{bc}}$ & $27.68 \pm 0.91^{\mathrm{ab}}$ & $69.20 \pm 1.37^{\mathrm{bcd}}$ & $47.85 \pm 0.98^{\mathrm{abc}}$ \\
$\mathrm{B}_{3} \mathrm{~T}_{2}$ & $62.87 \pm 1.09^{\mathrm{cd}}$ & $14.07 \pm 1.55^{\mathrm{a}}$ & $26.56 \pm 4.14^{\mathrm{ab}}$ & $69.25 \pm 3.61^{\mathrm{bcd}}$ & $47.89 \pm 1.98^{\mathrm{abc}}$ \\
$\mathrm{B}_{3} \mathrm{~T}_{3}$ & $61.80 \pm 1.56^{\mathrm{d}}$ & $12.68 \pm 2.04^{\mathrm{ab}}$ & $28.65 \pm 2.79^{\mathrm{a}}$ & $68.04 \pm 3.26^{\mathrm{cd}}$ & $49.49 \pm 0.25^{\mathrm{a}}$ \\
\hline $\mathrm{LSD}$ & 1.80 & 1.97 & 2.91 & 2.85 & 1.94 \\
\hline
\end{tabular}

Values are expressed as means \pm SD. Values in the same column with different superscript letters are significantly different from each other $(\mathrm{p}<0.05)$. 
Total color difference $(\Delta \mathrm{E})$ indicates the magnitude of color difference between stored and control samples (Patras et al., 2011). The values of $\Delta \mathrm{E}$ were significant $(p<0.05)$ difference due to the blending ratio and baking temperature. The $\Delta \mathrm{E}$ color value for cookies increased as incorporation level of Anchote flour increased similarly $\Delta \mathrm{E}$ of cookies significantly $(p<0.05)$ increased as baking temperature of cookies increased. The total color change $(\Delta \mathrm{E})$ of cookies did not exhibit significant $(p>0.05)$ differences due to the interaction between blending ratios and baking temperatures (Table 5). In fact, the cookies samples with $20 \%$ Anchote proportion baked at three baking temperature had $\Delta \mathrm{E}$ values of 47.85 to 49.49 with significant $(p<0.05)$ difference from 42.36 to 46.29 for control. On the other hand, the sample with $10 \%$ Anchote and whole wheat had the lowest $\Delta \mathrm{E}$ ranging from 42.36 to 46.71 with no statistically $(p>0.05)$ difference from each other.

\subsection{Sensory evaluation of cookies}

A seven-point hedonic scale was used to evaluate the acceptability of cookies in the sensory attributes. The results of the sensory evaluation such as color, taste, aroma, crispness and overall acceptability of cookies sample were judged by panelists as shown in Table 6 .

\subsubsection{Colour}

Colour is an important sensory attribute of any food because of its influence on acceptability. It also shows the suitable raw material used for the preparation, provides information about the formation and quality of the product. The color scores of the cookies significantly $(p<0.05)$ different due to blending ratios, baking temperatures and their interaction (Figure 2). The result indicated that cookies prepared from much Anchote flour lead to cookies of lower color acceptability scores. However, replacing 10\% Anchote flour in composite cookies did not cause significant $(p>0.05)$ difference from the control cookies. Thus, the score for color indicates various levels of liking in the 7-point hedonic scale. The color acceptability of cookies was more dominantly affected by baking temperature. The cookies baked at moderate temperature $\left(180^{\circ} \mathrm{C}\right)$ significantly higher color acceptable scores than that of the cookies baked at the 160 and $200^{\circ} \mathrm{C}$ baking temperatures. The darker color may be due to the Maillard reaction between reducing sugars and protein, which is normally encountered and desirable in baked goods (Dhingra and Jood, 2000).

\subsubsection{Taste}

Taste is the primary factor that determines the acceptability of any product, which has the highest impact as far as the market success of the baking product, is concerned. There were significant $(p<0.05)$ differences due to blending proportions and baking temperatures. The interaction between blending ratios and baking temperatures did not bring significance $(p>0.05)$ difference on taste score of cookies as shown in Table 5. The taste acceptability scores decreased as the Anchote incorporation increased. Another author, Alam et al. (2007) reported similar results for cookies for a decrease in taste score as the amount of sweet potato supplementation increased in wheat flour.In addition, the aroma score was more influenced by baking temperature rather than that of blending ratios. The highest score, 6.53 , was for cookies prepared from whole wheat flour and baked at $160^{\circ} \mathrm{C}$ and the lowest score, 5.23, was for cookies with $20 \%$ Anchote and baked at $200^{\circ} \mathrm{C}$.

Table 6. Effect of interaction of Anchote blend and baking temperature on the sensory acceptability of cookies

\begin{tabular}{cccccc}
\hline Code & Color & Taste & Aroma & Crispness & Overall Acceptability \\
\hline $\mathrm{WT}_{1}$ & $5.76 \pm 0.62^{\mathrm{c}}$ & $6.56 \pm 0.50^{\mathrm{a}}$ & $6.53 \pm 0.50^{\mathrm{a}}$ & $6.46 \pm 0.50^{\mathrm{a}}$ & $6.50 \pm 0.50^{\mathrm{a}}$ \\
$\mathrm{WT}_{2}$ & $6.70 \pm 0.46^{\mathrm{a}}$ & $6.06 \pm 0.44^{\mathrm{b}}$ & $6.23 \pm 0.50^{\mathrm{a}}$ & $6.10 \pm 0.54^{\mathrm{b}}$ & $6.40 \pm 0.49^{\mathrm{ab}}$ \\
$\mathrm{WT}_{3}$ & $5.73 \pm 0.63^{\mathrm{c}}$ & $5.96 \pm 0.55^{\mathrm{b}}$ & $5.93 \pm 0.36^{\mathrm{b}}$ & $5.80 \pm 0.55^{\text {de }}$ & $5.96 \pm 0.66^{\mathrm{cd}}$ \\
$\mathrm{B}_{1} \mathrm{~T}_{1}$ & $5.70 \pm 0.87^{\mathrm{c}}$ & $6.36 \pm 0.49^{\mathrm{ab}}$ & $6.40 \pm 0.49^{\mathrm{a}}$ & $6.36 \pm 0.55^{\mathrm{ab}}$ & $6.16 \pm 0.46^{\mathrm{bc}}$ \\
$\mathrm{B}_{1} \mathrm{~T}_{2}$ & $6.16 \pm 0.53^{\mathrm{b}}$ & $5.96 \pm 0.55^{\mathrm{b}}$ & $6.06 \pm 0.36^{\mathrm{ab}}$ & $5.86 \pm 0.62^{\mathrm{ce}}$ & $6.53 \pm 0.50^{\mathrm{a}}$ \\
$\mathrm{B}_{1} \mathrm{~T}_{3}$ & $5.73 \pm 0.69^{\mathrm{c}}$ & $5.83 \pm 0.59^{\text {bcd }}$ & $5.86 \pm 0.57^{\mathrm{ab}}$ & $5.83 \pm 0.64^{\text {edf }}$ & $5.60 \pm 0.62^{\mathrm{e}}$ \\
$\mathrm{B}_{2} \mathrm{~T}_{1}$ & $5.56 \pm 0.56^{\text {cd }}$ & $5.93 \pm 0.58^{\mathrm{bc}}$ & $6.00 \pm 0.64^{\mathrm{ab}}$ & $5.93 \pm 0.52^{\mathrm{c}}$ & $5.70 \pm 0.65^{\text {ed }}$ \\
$\mathrm{B}_{2} \mathrm{~T}_{2}$ & $6.33 \pm 0.83^{\mathrm{ab}}$ & $5.93 \pm 0.52^{\mathrm{bc}}$ & $5.33 \pm 0.71^{\mathrm{c}}$ & $5.96 \pm 0.56^{\mathrm{c}}$ & $6.43 \pm 0.64^{\mathrm{ab}}$ \\
$\mathrm{B}_{2} \mathrm{~T}_{3}$ & $5.20 \pm 0.92^{\mathrm{d}}$ & $5.60 \pm 0.56^{\text {ed }}$ & $5.53 \pm 0.68^{\mathrm{bc}}$ & $5.63 \pm 0.55^{\text {de }}$ & $5.53 \pm 0.57^{\mathrm{e}}$ \\
$\mathrm{B}_{3} \mathrm{~T}_{1}$ & $5.23 \pm 0.85^{\mathrm{d}}$ & $5.66 \pm 0.54^{\text {cde }}$ & $5.83 \pm 0.64^{\mathrm{b}}$ & $5.80 \pm 0.55^{\mathrm{e}^{\mathrm{ef}}}$ & $5.46 \pm 0.86^{\mathrm{e}}$ \\
$\mathrm{B}_{3} \mathrm{~T}_{2}$ & $5.63 \pm 0.80^{\mathrm{c}}$ & $5.43 \pm 0.56^{\mathrm{e}}$ & $5.46 \pm 0.77^{\mathrm{bc}}$ & $5.56 \pm 0.72^{\mathrm{e}}$ & $5.93 \pm 0.58^{\mathrm{cd}}$ \\
$\mathrm{B}_{3} \mathrm{~T}_{3}$ & $4.80 \pm 0.80^{\mathrm{e}}$ & $5.46 \pm 0.57^{\mathrm{e}}$ & $5.23 \pm 0.67^{\mathrm{c}}$ & $5.23 \pm 0.62^{\mathrm{f}}$ & $5.60 \pm 1.00^{\mathrm{e}}$ \\
\hline $\mathrm{LSD}$ & 0.37 & 0.27 & 0.38 & 0.29 & 0.32
\end{tabular}

Values are expressed as means \pm SD. Values in the same column with different superscript letters are significantly different from each other $(\mathrm{p}<0.05)$. 


\subsubsection{Aroma}

The aroma of Anchote - wheat composite cookies were significantly $(p<0.05)$ affected by the blending ratio, baking temperature but no significant influence on their interaction. Replacing $10 \%$ Anchote flour in composite cookies did not cause significant $(p>0.05)$ difference from whole wheat flour cookies. In addition, the aroma score was more influenced by baking temperature rather than that of blending ratios. The highest score, 6.53, was for cookies prepared from whole wheat flour and baked at $160^{\circ} \mathrm{C}$ and the lowest score, 5.23, was for cookies with $20 \%$ Anchote and baked at $200^{\circ} \mathrm{C}$. According to Fellows (2000), a very high temperature degrades some of the volatiles compounds produced and a burnt or smoky aroma is developed. However, the mean scores obtained for aroma; those possess an acceptable level, which ranged from like slightly to like very much sensory perception.

\subsubsection{Crispness}

Crispiness is defined as the force and noise with which a product breaks or fractures rather than deforms when chewed with the molar teeth (King, 2005). Significant $(p<0.05)$ differences were noted among blending proportions and baking temperatures. The data in Table 5 indicate that the interaction effect of Anchote blending ratios and baking temperatures has been exhibit significant $(p>0.05)$ difference on the crispness. The scores for the crispness of cookies were influenced by both factors equally. Also, during analyzing the hardness of cookies using an instrument, both blending ratios and the baking temperature had significant $(p<0.05)$ effect on the hardness of the cookies. The score for crispiness ranged from 5.23 for cookies with $20 \%$ Anchote and $200^{\circ} \mathrm{C}$ of baking temperature to 6.46 for cookies prepared from whole wheat and $160^{\circ} \mathrm{C}$ of baking temperature, with statistically $(p>0.05)$ different from each other. However, their differences were among very few samples and the majorities are not different from each other.

\subsubsection{Overall acceptability}

The data regarding the overall acceptability of control and composite flours cookies are shown in Table 5 . The result was significant $(p<0.05)$ differences among acceptability scores due to blending proportions of Anchote and baking temperatures and their interaction (Figure 2). The scores regarding overall acceptability ranged from 5.66 to 6.5 that means all the scores achieved above 5 in 7-point hedonic scale indicated moderate liking and above. No significant $(p>0.05)$ difference on the overall acceptability of cookies was observed between samples of whole wheat flour and those with 15\% substituted Anchote flour.

However, all the wheat - Anchote composite flours cookies were accepted by consumer having a sensory scored for overall acceptability more than five. Knuckles et al. (1997) reported that in sensory evaluation, products with a score value of more than five for overall acceptability can be considered as a good quality product. Substituting the Anchote flour up to $15 \%$ for cookies preparation did not bring statistical $(p<0.05)$ difference from the control cookies prepared from whole wheat flour in sensory attributes.

\section{Conclusion}

Anchote is one of the indigenous tuber crops with wonderful nutritional and economical resources in south and southwestern part of Ethiopia. The use of Anchote flour to supplement wheat flour on the baking could substantially reduce wheat flour imports and increase the value of Anchote. The Anchote flour prepared from Anchote tuber was blended with wheat flour at different blending proportions (10, 15 and 20\%) for preparing composite flour cookies. This study revealed that baked products which contained Anchote exhibited good physical properties. The cookies containing 15\% Anchote flour and baked at moderate temperature $\left(180^{\circ}\right.$ C) were highly acceptable in terms of organoleptic qualities compared to other tested products. This could lead to the development of fiber content and gluten-free cookies. Anchote is one of the best tuber crops in respect of protein and another nutrient source. Therefore, it is recommendable to incorporate Anchote in new products for diversification and simultaneously for increasing Anchote value chain is very important.

\section{Conflict of interest}

The authors declared no conflict of interest.

\section{Acknowledgments}

The authors would like to acknowledge the financial assistance provided by Wollega University under Ministry of Education.

\section{References}

AACC. (2000). Approved Methods of the American Association of Cereal Chemists. 9th ed. Eagan, Minnesota USA: AACC.

Abebe, D. and Hagos, E. (1991). Plants as a primary source of drugs in the traditional health practices of Ethiopia. In Eagles, J.M.M., Hawkes, J.G. and Worede, M. (Eds.) Plant genetic resources of Ethiopia, p. 101-113. Cambridge: Cambridge 
University Press. https://doi.org/10.1017/ CBO9780511551543.007

Abebe, H., Tesema, B. and Tilku, D. (2018). Proximate Compositions, Anti Nutritional Factors and Minerals Content of Composite Flours and Bread from Blends of Wheat-Anchote-soybean flour. Advances in Food and Nutrition, 3(1), 1-9. https://doi.org/10.33140/ ANFS/03/01/00001

Adebayo, A.S. and Itiola, O.A. (2003). Effect of breadfruit and cocoyam starch mucilage binders on disintegration and dissolution behaviours of paracetamol Tablet formulations. Pharmaceutical Technology, 27(3), 78-90.

Adebowale, R., Sanni, S.A. and Oladapo, F.O. (2008). Chemical, functional and sensory properties of instant yam-breadfruit flour. Nigerian Food Journal, 26, 2-12. https://doi.org/10.4314/nifoj.v26i1.47417

Adeleke, R.O. and Odedeji, J.O. (2010). Functional properties of wheat and sweet potato flour blends. Pakistan Journal of Nutrition, 9(6), 555-557. https:// doi.org/10.3923/pjn.2010.535.538

Adetuyi, F.O., Badejo, O.F., Ikujenlola, A.V. and Omosuli, S.V. (2009). Storage influence on the functional properties of malted and unmalted maize (Zeamays L SSP mays) and Soybean (Glycine max L Merill) flour blends. African Journal of Food Science, 3(2), 56-60.

Agren, G. and Gibson, R.S. (1969). Food Composition Table for Use in Ethiopia. Children's Nutrition Unit (CNU) report no. 16. Stockholm: Almovist and Wiksell bokhandel

Ajanaku, K.O., Ajanaku, C.O., Edobor-Osoh, A. and Nwinyi, O.C. (2012). Nutritive value of Sorghum Ogifortifed with groundnut seed (Arachis hypogaeaL.). American Journal of Food Technology, 7(2), 82-88. https://doi.org/10.3923/ ajft.2012.82.88

Alam, S., Shah, H., Ullah, S. and Riaz, A. (2007). Comparative studies on storage stability of ferrous iron in whole wheat flour and flat bread (naan). International Journal Food Science and Nutrition, 58(1), $\quad 54 \quad-\quad 62 . \quad 6 h t$ doi.org/10.1080/09637480601121979

Anis, J.M., Wan Rosli, W.I and Daniel, R.S. (2014). Physicochemical and Sensorial Evaluation of Biscuit and Muffin Incorporated with Young corn powder. Sains Malaysiana, 43(1), 45-52.

AOAC. (2000). Association of Official Analytical Chemists. Official methods of Analysis. Vol. 2, $17^{\text {th }}$ ed. Washington, DC, USA. AOAC.

Ashogbon, A. and Akintayo, E. (2012). Morphological, functional and pasting properties of starches separated from rice cultivars grown in Nigeria.
International Food Research Journal, 19(2), 665671.

Ayinde, F.A. and Dinrifo, R.R. (2001). Effect of storage and pre-storage treatments on the quality of dried sweet potato slices. Annals of Agricultural Sciences, 22(1), 16-20.

Ayo, J.A., Ayo, V.A., Nkama, I. and Adeworie, R. (2007). Physiochemical, in-vitro digestibility and organoleptic evaluation of acha-wheat biscuit supplemented with soybean flour. Nigerian Food Journal, 25(1), 15-17. https://doi.org/10.4314/ nifoj.v25i1.33656

Baik, O.D., Marcotte, M. and Castaigne, F. (2000). Cake baking in tunnel type multi-zone industrial ovens. Part I, Characterization of baking conditions. Journal of Food Research International, 33(7), 587598. https://doi.org/10.1016/S0963-9969(00)00095-8

Bekele, E. (2007). Study on actual situation of medicinal plants in Ethiopia. Retrieved from website: http:// jaicaf.or.jp/publications/ethiopia_ac.pdf

Bekele, T., Kassa, K., Mengistu, T., Debele, M. and Melka, Y. (2013). Working with communities to address deforestation in the Wondo Genet Catchment Area, Ethiopia: Lessons learnt from a participatory action research. Research Journal of Agriculture and Environmental Management, 2(12), 448-456.

Beruk, B.D., Fikre, T.T. and Dereje, H. (2015). Physical and proximate characterization of Anchote (coccinia abyssinica) accessions grown under Hawassa and Wondo Genet conditions, Southern Ethiopia. Food Science and Quality Management, 42, 62-74.

Chauhan, A., Saxena, D.C. and Singh, S. (2015). Total dietary fiber and antioxidant activity of gluten free cookies made from raw and germinated amaranth (Amaranthus spp.) flour. LWT-Food Science and Technology, 63(2), 939-945. https://doi.org/10.1016/ j.lwt.2015.03.115

Chauhan, A., Saxena, D.C. and Sukhcharn, S. (2016). Physical, textural, and sensory characteristics of wheat and amaranth flour blend cookies. Cogent Food and Agriculture, 2(1), 1125773 https:// doi.org/10.1080/23311932.2015.1125773

Chefel, J.C., Cuq, J.L. and Lorient, D. (1989). Prote'inas Alimentarias, Bioqu'imica, Propiedades Funcionales. Spain: Acribia. [In Spanish].

Chiemela, E., Charles, C. and Joseph, O. (2013). Chemical composition, functional and pasting properties of cassava starch and soy protein concentrate blends. Journal of Food Science and Technology, 50(6), 1179-1185. https:// doi.org/10.1007/s13197-011-0451-8

Das, L., Utpal, R. and Runu, Ch. (2012). Effect of baking 
conditions on the physical properties of herbal bread using RSM. International Journal of Food, Agriculture and Veterinary Sciences, 2(2), 2277-209.

Demelash, H. (2016). Quality analysis of breads produced from blendes of wheat (Triticum aestivum L.) and Anchote (Coccinia abyssinica L.). Journal Science, Technology and arts research, 5(1), 61-68. https://doi.org/10.4314/star.v5i1.9

Dhingra, S. and Jood, S. (2000). Organoleptic and Nutrition evaluation of wheat breads supplemented with soybean and barley flour. Journal of Food Chemistry, 77(4), 479-488. https://doi.org/10.1016/ S0308-8146(01)00387-9

Ehimen, R., Abiodun, A., Adeniyi, A., Raphael O., Ayansina, O. and Ayorinde, F. (2017). Nutrient composition, functional, and pasting properties of unripe cooking banana, pigeon pea, and sweet potato flour blends. Journal of Food Science, 5(3), 455. https://doi.org/10.1002/fsn3.455

Eriksson, E., Koch, K., Tortoe, D., Akonor, P. and Baidoo, E. (2014). Physicochemical, functional and pasting characteristics of three varieties of cassava in wheat composite Flours. British Journal of Applied Science and Technology, 4(11), 1609-1621. https:// doi.org/10.9734/BJAST/2014/7987

Giami, S. and Bekebian, D. (1992). Proximate composition and functional properties of raw and processed full fat fluted pumpkin (Telfairia occidentalis) seed flour. Journal of the Science of Food and Agriculture, 59, 321-325. https:// doi.org/10.1002/jsfa.2740590308

Habtamu, F. (2011). Effect of traditional processing methods on nutritional composition and antinutritional factors of Anchote (Coccinia abyssinica (Lam.) Cogn) grown in western Ethiopia. Addis Ababa: Addis Ababa University, MSc. Thesis.

Habtamu, F. (2014). Effects of Boiling Methods on Antinutritional Factors of Anchote (Coccinia abyssinica (lam.) Cogn) tubers Grown in Western Ethiopia. Food Science and Quality Management, 27, 39-40.

Habtamu, F. and Kelbessa, U. (1997). Nutritional and ant nutritional characteristics of Anchote (Coccinia abyssinica). The Ethiopia Journal of Health Development, 11(2), 163-168.

Habtamu, F., Fekadu, B. and Gullelat, D. (2013). Effect of Traditional Processing Methods on Nutritional Composition and Anti-nutritional Factors of Anchote (Coccinia abyssinica (lam.) Cogn) tubers grown in Western Ethiopia. Journal of Food Process Technology, 4(7), 1-8.

Habtamu, Sh. (2013). Effect of Processing on Physicochemical and Antinutritional Factors of "Anchote" (Coccinia abyssinica) and Development of Value Added Biscuit. Addis Ababa: Addis Ababa University, MSc. Thesis.

Hora, H. (1995). Anchote: An endemic tuber crop. Jimma College of Agriculture, Jimma, Ethiopia.

Hsu, C.L., Chen, W., Weng, Y.M. and Tseng, C.Y. (2003). Chemical composition, physical properties, and antioxidant activities of yam flours as affected by different drying methods. Food Chemistry, 83(1), 85-92. https://doi.org/10.1016/S0308-8146(03) 00053-0

Jan, S., Insha, S. and Saxena, D.C. (2015). Effect of physical properties on flow ability of commercial rice flour/powder for effective bulk handling presented at the $3^{\text {rd }}$ International Conference on Advancement in Engineering and Technology, March 2015. Sangrur, Punjab, India.

Jemziya, M. and Mahendran, T. (2015). Quality characteristics and sensory evaluation of cookies produced from composite blends of sweet potato (Ipomoea batatas L.) and wheat (Triticum aestivum L.) flour. Journal of Food and Agriculture, 1(2), 2330. https://doi.org/10.4038/sljfa.v1i2.16

Julianti, E., Rusmarilin, H. and Yusraini, R. (2015). Functional and rheological properties of composite flour from sweet potato, maize, soybean and xanthan gum. Journal of the Saudi Society of Agricultural Sciences, 16(2), 171 - 177. https://doi.org/10.1016/ j.jssas.2015.05.005

Knuckles, B.E., Hudson, C.A., Chiu, M.M. and Sayre, R.N. (1997). Effects of $\beta$-glucan barley fractions in high-fiber bread and pasta. Cereal Food World, 42 (2), 94-99.

Lawless, H.J. and Heymann, H. (Eds.) (1999). Acceptance and preference testing. In Sensory Evaluation of Food. Boston, USA: Springer. https:// doi.org/10.1007/978-1-4615-7843-7_13

Leach, H.W., Cowen, L.D. and Schoch, T.J. (1959). Structure of the starch granules, in: Swelling and solubility patterns of various starches. Cereal Chemistry, 36, 534-544.

Lesego, B. (2014). Physico-functional properties of wheat-morama bean composite flour and its performance in food systems. Ghana: University of Ghana, MSc. Thesis.

Manley, D. (1998). Manual for Baking and Cooling of Biscuits. Cambridge, United Kingdom: Wood head Publishing Limited.

Mateusz, S., Marek, M., Ireneusz, O. and Wioletta, B. (2013). Mechanical properties of native maize, wheat, and potato starches. Czech Journal of Food Science, 31(4), 347-354. https:// doi.org/10.17221/348/2012-CJFS

Mengesha, D., Belew, D., Gebrasillasie, W. and Sori, W. 
(2012). Growth and Yield Performance of Anchote. Asian Journal of Plant Sciences, 11(4), 172-181. https://doi.org/10.3923/ajps.2012.172.181

Okaka, J.C. and Okaka, A. (2001). Food composition, spoilage and shelf life extension, p. 54-56. Enugu, Nigeria: ocjarc' o Academic Publishers.

Olapade, A. and Adeyemo, A. (2014). Evaluation of cookies produced from blends of wheat, cassava and cowpea flours. International Journal of Food Studies, 3, 175-185. https://doi.org/10.7455/ ijfs/3.2.2014.a4

Oluwakemi, F., Adewale, O., Olajide, P., Adebukunola, M., Mojisola, O., Olatundun, E., Abdul-Rasaq A., Silifat A., Lateef O. and TomLins K. (2017). Nutritional composition, functional and pasting properties of wheat, mushroom, and high quality cassava composite flour. Journal Food Process Preservation, 41(5), 13-150. https://doi.org/10.1111/ jfpp. 13150

Oyewole, O.B. (2002). The powers at the roots, foods and its microbial allies. UNAAB Inaugural Lecture Series No. 15. Abeokuta, Nigeria: Federal University of Agriculture.

Palatnik, D.R., Ostermann-Porcel, M.V., Gonzalez, U., Zaritzky, N. and Campderros, M.E. (2015). Recovery of caprine whey protein and its application in a food protein formulation. LWT-Food Science and Technology, 63(1), 331-338. https:// doi.org/10.1016/j.lwt.2015.03.027

Pareyt, B., Wilderjans, E., Goesaert, H., Brijs, K. and Delcour, J.A. (2008). The role of gluten in a sugarsnap cookie system: a model approach based on gluten-starch blends. Journal of Cereal Science, 48 (3), $\quad 863-869 . \quad$ https://doi.org/10.1016/ j.jcs.2008.06.011

Patras, A., Brunton, N.P., Tiwari, B. and Butler, F. (2011). Stability and degradation kinetics of bioactive compounds and colour in strawberry jam during storage. Food and Bioprocess Technology, 4, 1245-1252. https://doi.org/10.1007/s11947-0090226-7

Peter, A., Okafor, D., Kabuo, N.O., Ibeabuchi, J.C., Njideka, N.E. and Mbah, N. (2017). Production and evaluation of cookies from whole wheat and date palm fruit pulp as Sugar Substitute. International Journal of Advancement in Engineering Technology, Management and Applied Science, 4, 2349-3224.

Shibukawa, S., Sugiyama, K. and Yano, T. (1989). Effects of Heat Transfer by Radiation and Convection Browning of Cookies at Baking. Journal of Food Science, 54(3), 621-699.

Sibanda, S. and Sychawska, B. (2000). A comparative study of wild yam starch from Dioscore aschimperiana. Journal of Applied Science South Africa, 6, 79-86. https://doi.org/10.4314/ jassa.v6i2.16841

Singh, G.D., Riar, C.S., Saini, C., Bawa, A.S. and Saxena, D.C. (2011). Indian water chestnut flour method optimization for preparation, its physicochemical, morphological, pasting properties and its potential in cookies preparation. LWT - Food Science Technology, 44(3), 665-672. https:// doi.org/10.1016/j.lwt.2010.09.015

Sudha, M.L., Vetrimani, R. and Leelawathi, K. (2007). Influence of fiber from different cereals on the rheological characteristics of wheat flour dough and on biscuit quality. Food Chemistry, 100(4), 13641370.

https://doi.org/10.1016/ j.foodchem.2005.12.013

Sze, T.K. and Sathe, S.K. (2000). Functional properties and in vitro digestibility of almond (Prunus dulcisL.) protein isolate. Food Chemistry, 69(2), 153-160. https://doi.org/10.1016/S0308-8146(99)00244-7

Temesgen, L., Abebe, H. and Tigist, F. (2015). Production and Quality Evaluation of Cookies Enriched with $\beta$-Carotene by Blending OrangeFleshed Sweet Potato and Wheat flours for Alleviation of Nutritional Insecurity. International Journal of Food Science and Nutrition Engineering, 5(5), 209-217.

Woolfe, J.A. (Ed.) (1992). Post-harvest procedure: II Processing, In Sweet potato: an untapped food resource, p. 294-355. United Kingdom: Cambridge University Press.

Xue, J. and Walker, C.E. (2003). Humidity change and its effects on baking in an electrically heated air jet impingement oven. Journal of Food Research International, 36(6), 561-569. https:// doi.org/10.1016/S0963-9969(02)00221-1

Yambo, Y. and Feyissa, T. (2013). Micropropagation of Anchote [Coccinia abyssinica (Lam.) Cogn.], High calcium content tuber crop of Ethiopia. African Journal of Agricultural Research, 8(46), 5915-5922.

Yassin, H., Ali, M., Desta, F. and Seid, H. (2013).Effect of Flower Bud Removal on Growth and Yield of Anchote Root (Coccinia abyssinica (Lam.) Cogn.) accessions at Bishoftu. Advanced Research Journal of Plant and Animal Sciences, 1(1), 7-13.

Zhu, K.J., Kanu, I.P., Claver, K., Zhu, H., Qian, H. and Zhou, H. (2009). A method for evaluating Hunter whiteness of mixed powders. Advanced Powder Technology, 20(2), 123-126. https://doi.org/10.1016/ j.apt.2008.04.001 